\begin{tabular}{|l|l|l|l|l|}
\hline Profile & S-y Cheng & $\begin{array}{l}\text { Understanding thyroid hormone } \\
\text { actions }\end{array}$ & 22:2 & P1-P10 \\
\hline &
\end{tabular}

\section{My journey to unravel complex actions of thyroid hormone: was it fate or destiny?}

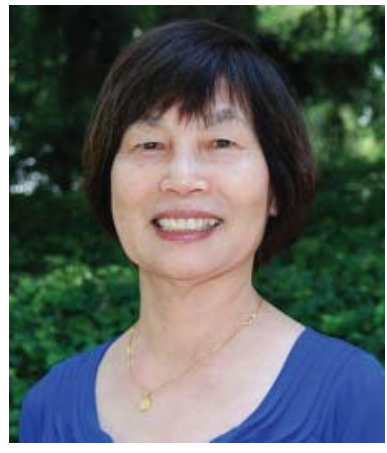

Laboratory of Molecular Biology, Center for Cancer Research, National Cancer Institute, National Institutes of Health, 37 Convent Drive, Room 5128, Bethesda, Maryland 20892-4264, USA
I am the youngest of five children in a Chinese family. My father was deprived of a high school education because he needed to help my grandfather's family business. During my father's childhood living in a small village in Southern Taiwan, it was very common that children were not encouraged to seek education beyond the elementary school level, as the few high schools in the country were located many miles away and because the financial needs of the families had precedence. However, my father was a self-educated man. While learning how to run a business from my grandfather, he somehow got hold of a copy of Analects of Confucius (Lúnyû), a collection of sayings and ideas attributed to the Chinese philosopher Confucius and his contemporaries. My father believed in the essence of the Confucian teaching that students should become ethically wellcultivated men. They should be devoted to their parents and older siblings and should carry themselves with dignity, and embody integrity and virtues in all things. When my father did not understand the words in Lúny he would look them up in the dictionary. When the meaning of the sentences confounded him, he would stop by to see his teachers at the elementary school for clarification. Those teachers, realizing my father's thirst for learning, voluntarily tutored him at nights in other subjects taught at the high school level: mathematics, geography, history, and Chinese literature. However, I believe that it was Confucius' teachings that had shaped what my father was: a man who was disciplined, diligent, and respectful of parents; one who listened more and spoke less, and, above all, who held a deep reverence and admiration for scholars and a strong belief in the value of education.

Desiring to provide his children with the opportunity for a higher education that he never had, he moved our family to Tainan, a large city in Southern Taiwan, after my first elder sister was born. However, the schools were still miles away from where we lived. I vividly remember my father accompanying me to my first day of junior high school, both of us on a single bicycle making the journey on a blazingly hot September day. He did the pedaling while I sat on the steel bar between the bicycle seat and the handles. I remember hearing his labored breathing from pedaling uphill on gravel roads and feeling his hot sweat drip on my neck. I sensed his dreams and hopes for me to become a scholar were there in each labored push of the bicycle pedals on that blazing hot day. I will never forget that day and know that whatever I have accomplished professionally, I owe to my father's values and the model he set.

To attend a good college in Taiwan at my time, a person had to pass the highly competitive entrance examinations. High school students worked long and hard to prepare for the entrance examinations. However, there was a prestigious award system bestowed in a few high schools in Taiwan whose students had a track record of high scores on the entrance examinations. These schools were allotted a certain number of students who could enter the best universities without having to take

Published by Bioscientifica Ltd. 
the entrance examination. I was fortunate enough to graduate first in my class from one of these high schools, and so the entrance examination requirement was waived for me. I entered the National Taiwan University in Taipei, the capital city of Taiwan, where I could choose any majors I desired. I wanted to go to the 7-year medical school at the National Taiwan University, the best medical school at that time. My father, however, thought that the medical profession would pose a hardship for a woman. Perhaps, he also viewed the profession of a physician as something intellectually beneath the life of a scholar.

In the end, I attended the School of Pharmacy at the National Taiwan University. From time to time, I cannot help wondering what my professional life might have been like had I defied my father's wishes and taken the path to become a physician. But I have never regretted the decision to enter the School of Pharmacy, which offered an excellent and balanced curriculum in all aspects of basic science and provided a nurturing learning environment that prepared me to focus on any biomedical field that I was interested in for my PhD studies.

Upon graduating from the School of Pharmacy, I applied for admission to several graduate programs in the USA where teaching assistantships or scholarships were available. As I had graduated first in my class, those undergraduate academic credentials made possible my admission to the Department of Pharmaceutical Chemistry, School of Pharmacy at the University of California San Francisco Medical Center, with a teaching assistantship to support my PhD studies. I cannot forget the tears in my father's eyes as he bid me goodbye in a choked voice at the airport before my flight to San Francisco. His dreams and hopes for me to become a research scholar were beginning to be fulfilled as I began my voyage to pursue the advanced degree essential for such a career. Still I wonder whether my father's tears were from joy over a dream about to come true, or from sadness about the possibility that he might not see me for years while I was realizing his dreams in a foreign land?

After completing the 2-year course work, I wandered through rotations in different departments of the School of Pharmacy intended for the selection of thesis advisors. But I could not decide what research topics would be important to study. Was it fate that I was offered a research fellowship under the guidance of Dr Manfred Wolff that would launch my lifetime interest in understanding the molecular mechanisms of hormone actions?

The project was to synthesize androgen analogs, evaluate their in vivo biological activities by androgenicmyotropic assays, and understand the essential structural features critical for interaction with the hormone receptors. I was fascinated by the prospect that one can make a hormone analog that could be stronger than a natural hormone to benefit humans. During the 2-year-long project, including the intermediates, I had synthesized 33 non-classical androgen analogs. To my disappointment, none of them was more active than the natural hormone testosterone. However, my thesis work had uncovered a few novel synthetic routes to make androgen analogs and identified the steric requirements on the $\beta$-face of rings $A, B$, and $C$ and the $\alpha$-face of ring $\mathrm{D}$ of the androgens for interaction with the receptors. My thesis work had introduced me to the concept of a receptor, how hormones could work in vivo, and the challenging, joyful, disappointing, and rewarding experiences in research.

I got married after I received my $\mathrm{PhD}$, but my husband was in his last year of $\mathrm{PhD}$ studies to complete his thesis at the Department of Material Sciences, the University of California at Berkeley, California. During that time, I continued to work at Dr Wolff's laboratory to wrap up some unfinished experiments. After my husband received his $\mathrm{PhD}$, he accepted an associate research position at the Argonne National Laboratory. Together with a newborn son, we moved to Hinsdale (a suburb of Chicago) near the laboratory. Again, was it fate that I my first postdoctoral position was working with Dr Elwood Jensen at the Ben May Laboratory for Cancer Research, University of Chicago? Dr Jensen was a pioneer and visionary leader in the field of steroid hormone action. In a series of landmark papers on estrogen actions, he laid the foundations of how steroid hormones could act in cells. Building on his work, the field was rapidly expanded by many others and had greatly flourished to become what we know today. Before he died, he was viewed as a strong contender for the Nobel Prize in physiology or medicine.

While working in Dr Jensen's laboratory, the hormone receptors became more real to me than when I was a PhD graduate student, because my project was to attempt to enrich estrogen receptors extracted from calf uterus. I would go early in the mornings to the slaughterhouse to collect calf uterus and spent long hours in the cold room aiming to enrich estrogen receptors by classical chromatography. I monitored the presence of estrogen receptors by sucrose gradient centrifugation during each chromatographic step. At the time, Dr Jensen's laboratory routinely analyzed breast cancer samples for the presence or absence of estrogen receptors for diagnosis and to determine treatment options. I learned that a hormone

Published by Bioscientifica Ltd 
could be an angel bestowing one's good health, but could even be a devil driving cancer development.

Regrettably, my postdoctoral fellowship with Dr Jensen was short lived. After 1 year, my husband accepted an offer to work at the US Department of Energy's Nuclear Regulatory Commission. In our household, the priority was always given to my husband's career development. Now with two preschoolers, we moved to Bethesda, Maryland. The upside to this relocation that took me away from my fellowship position with Dr Jensen was that my husband's office was located in downtown Bethesda near the National Institutes of Health (NIH). I was thrilled with the possibility that I might find my second postdoctoral position at NIH, but I was hugely disappointed when none of the many copies of my $\mathrm{CV}$ that I sent out got a positive response. In desperation, with copies of my CV in hand like a sales representative, I worked my way from floor to floor, laboratory to laboratory in Building 10 of NIH asking about openings for a postdoctoral fellowship.

Was it fate again that I was offered a fellowship position after I knocked on the door of Dr Han Cahnmann's laboratory on the 8th floor of Building 10 ? Dr Cahnmann was an internationally known chemist/ biologist specializing in thyroid hormone analogs and their biology. Dr Cahnmann collaborated closely with Drs Jacob Robbins, Harold Edelhoch, and Ed Rall, who were the founding members of the Clinical Endocrinology Branch (CEB) of the National Institutes of Diabetes, Digestive and Kidney Diseases (NIDDK). Little did I know that I just stepped into one of the best laboratories in the world on thyroid hormone actions when I accepted the postdoctoral fellowship offered by Dr Cahnmann. The CEB was staffed by exceptional investigators, deeply passionate about how thyroid hormones are synthesized in the thyroid gland, how tyrosines are iodinated and coupled in thyroglobulin to form tetra-iodothyronine $\left(\mathrm{T}_{4}\right)$ and tri-iodothyronine $\left(\mathrm{T}_{3}\right)$, how $\mathrm{T}_{3}$ and $\mathrm{T}_{4}$ are transported from the gland to target tissues, how the structures of thyroid hormones and analogs affect functions, and how thyroid hormones interact with the two high-affinity serum thyroid hormone-binding proteins, transthyretin and thyroxine-binding globulin, thereby affecting their functions. I had the privilege to work not only with Dr Cahnmann, but also with Drs Robbins, Edelhoch, and Rall on the understanding of the structure, functions, and biology of transthyretin and thyroxinebinding globulin. The collegial interactions and productive collaborations at the CEB led to many important discoveries in the field.
The prominence and openness of the CEB had attracted streams of international thyroid biologists, endocrinologists, fellows, and seasoned thyroidologists as visiting scientists, and that further elevated the CEB's international standing and recognition. My 5-year postdoctoral training was in a stimulating and inspiring environment that greatly expanded my understanding of hormone actions. I also learned about the tools and methodologies that one can use to study how hormones can bind to their binding proteins and receptors. The opportunity to interact with international scientists at the CEB had taught me that research is a universal pursuit and global collaborations facilitate discoveries. The positive experiences in the thyroid hormone world of the CEB convinced me that being a researcher in the thyroid hormone field is a good thing. Importantly, I was amazed at how a small-molecule hormone, $\mathrm{T}_{3}$, can elicit remarkable biological activities related to growth, development, differentiation, and maintaining metabolic homeostasis. Its importance is crystal clear in that its absence during development leads to the profoundly deleterious effects of cretinism, as exemplified in congenital hypothyroidism. Indeed, there was so much yet to learn and to uncover about how $\mathrm{T}_{3}$ acts in cells to maintain a person's well-being, I decided to focus my work on elucidating molecular mechanisms by which $\mathrm{T}_{3}$ functions at the cellular levels.

The development of my independent research began with an invitation to collaborate on a project from Dr Ira Pastan, the Chief of the Laboratory of Molecular Biology (LMB) at the National Cancer Institute (NCI). Dr Pastan is a creative and brilliant physician-scientist who had opened many new and exciting areas of research in cell biology. He has received many prestigious awards for his work and is a member of the US National Academy of Sciences. At the time, Dr Pastan was interested in understanding how growth factors and other biologically important large molecules enter the cells to exert their functions. In a series of seminal papers, Dr Pastan, together with Dr Mark Willingham, a talented and renowned cell biologist and pathologist, elegantly showed that the entry of large molecules, such as $\alpha 2$-macroglobulin, and growth factors, such as insulin and epidermal growth factor (EGF), was via receptor-mediated endocytosis. The entry of these molecules into cells and their subsequent transit through different cellular compartments were directly visualized by intensification fluorescence microscopy (Maxfield et al. 1978, Willingham \& Pastan 1978). Dr Pastan wondered whether a small-molecule hormone, such as $\mathrm{T}_{3}$ could also use the same mode of entry into cells, as opposed to the general belief at the time that $\mathrm{T}_{3}$ entered the cells

Published by Bioscientifica Ltd. 
via a simple diffusion process. To test the possibility, biologically active rhodamine-labeled $\mathrm{T}_{3}$ was needed. On the basis of my training in synthetic chemistry during my PhD work and postdoctoral work with Dr Cahnmann, Dr Pastan believed that I was the best qualified person to collaborate with him on this quest by synthesizing rhodamine-labeled $T_{3}$ to use as a probe. I successfully conjugated rhodamine to $T_{3}$, purified the conjugate, and showed that it had maintained sufficient activity for the cell-uptake studies. Indeed, using intensification fluorescence microscopy, we visualized the entry of $T_{3}$ into living fibroblasts via the coated pits on the cell surface as shown for $\alpha 2$-macroglobulin and growth factors. Thus, a saturable, energy-dependent receptor-mediated process for the specific uptake of $\mathrm{T}_{3}$ existed in fibroblasts (Cheng et al. 1980). The success of this initial collaborative work was followed by an offer from Dr Pastan to join the LMB as a tenured independent investigator.

This position allowed me to begin my quest first to attempt to purify the membrane receptors that mediate the specific uptake of $\mathrm{T}_{3}$. Using bromoacetyl-radiolabeled $\mathrm{T}_{3}$ as an affinity-labeling reagent, we found a membrane receptor to be present not only in human fibroblasts and human A431 carcinoma cells, but also in rat GH3 cells, a cell line frequently used to study $\mathrm{T}_{3}$ actions. It migrated with an apparent molecular weight of $55 \mathrm{kDa}$ in gel electrophoresis. We designated this protein $\mathrm{p} 55$. At the time, before cloning of thyroid hormone receptors (TRs; reported in late 1986), our hypothesis was that this membrane receptor could be somehow homologous to the nuclear receptors, and this membrane receptor, in addition to its function in $\mathrm{T}_{3}$ cellular uptake, could have some membrane-initiated functions similar to those of the tyrosine kinase receptors (e.g., for insulin) on the plasma membrane. Thus, the membrane-receptorinitiated functions of $\mathrm{T}_{3}$ could account for some of the diversified biological activities of $T_{3}$. At the time, it was known that the biological activities of $\mathrm{T}_{3}$ were mainly mediated by the nuclear receptors. The similar molecular weight $(55 \mathrm{kDa})$ to that of nuclear receptors $(50-55 \mathrm{kDa})$ determined biochemically gave us high hope that we might find what we were looking for, such that it could be a groundbreaking discovery. This idea excited us and drove us relentlessly to finally purify a membraneassociated $\mathrm{T}_{3}$-binding protein from human A431 carcinoma cells (Cheng et al. 1986).

We were intrigued by the findings that p55 was mainly localized to the nuclear envelope and endoplasmic reticulum, but not on the cell surface plasma membrane, nor to the nucleus. The unexpected subcellular localization of p55 was explained by the subsequent cloning of p55 cDNA, which revealed that p55 was homologous to protein-disulfide isomerase and the $\beta$-subunit of Prolyl 4-hydroxylase (Cheng et al. 1987) and, therefore, that it is another cellular thyroid hormonebinding protein. This setback, however, did not deter us from the continued quest to hunt for and purify the elusive $\mathrm{T}_{3}$ membrane receptor. Indeed, we purified another cytosolic $\mathrm{T}_{3}$-binding protein from human A431 cells with an apparent molecular weight of $58 \mathrm{kDa}$ (p58) (Kitagawa et al. 1987). Cloning of the p58 cDNA revealed that it is a monomer of pyruvate kinase (Kato et al. 1989) and was not the membrane receptor that we were hunting for. While $\mathrm{p} 58$ was shown to regulate $\mathrm{T}_{3}$ functions (Ashizawa et al. 1991, 1992, Ashizawa \& Cheng 1992), with huge disappointment, I came to the conclusion that the classical approach of protein-by-protein purification might not be an efficient and effective approach for identifying the plasma membrane receptor responsible for the saturable and energy-dependent $T_{3}$ uptake. However, the limited resources of my small research group precluded me from any further hunt for the identity of the elusive $\mathrm{T}_{3}$ plasma membrane receptor.

Even today, I wonder about the molecular identity of the saturable $T_{3}$ membrane receptor visualized by intensification fluorescence microscopy years ago (Cheng et al. 1980). Was it related to the monocarboxylate transporter 8 (MCT8) or the organic anion polypeptide 1c1 (OATP1C1) that have recently been shown to transport thyroid hormones into cells (Mayerl et al. 2014, Schweizer et al. 2014)? Is it possible that it could be related to $\alpha \mathrm{v} \beta 3$ integrin that has been shown in many cell types to be the membrane TR (Davis et al. 2011, Lin et al. 2011)? We will never know the answer until additional experiments are performed specifically with the aim of addressing this question.

The groundbreaking reports on the cloning of the cDNAs encoding the two TRs, $\alpha$ and $\beta$, in December of 1986 (Sap et al. 1986, Weinberger et al. 1986) redirected the course and focus of my research. TRs are ligand-dependent transcription factors that mediate the genomic activities of $\mathrm{T}_{3}$. TR isoforms are expressed in a tissue-dependent manner. TR $\alpha 1$ is predominantly expressed in the brain, heart, and skeletal muscle, and TR $\beta 1$ is expressed mainly in the liver, kidney, and thyroid. The transcriptional activity of TRs is modulated by a host of nuclear receptor coregulators (Cheng et al. 2010). TRs regulate target genes in the presence or absence of $\mathrm{T}_{3}$ via recruitment of coregulatory complexes. In the absence of $T_{3}$, in target genes that are positively regulated by $T_{3}$,

Published by Bioscientifica Ltd 
TRs recruit the nuclear corepressors NCOR1 and NCOR2 for transcriptional repression. The presence of $\mathrm{T}_{3}$ leads to a conformational change in the TR that releases the NCOR1/NCOR2 complex and allows for the recruitment of a multiprotein coactivator complex for transcriptional activation.

For years, the genetic basis of a disorder known as thyroid hormone resistance (RTH), discovered by Refetoff et al. (1967), could not be identified. RTH is a syndrome characterized by reduced sensitivity of tissues to the action of thyroid hormones. This condition is characterized by elevated levels of circulating thyroid hormones associated with normal or high levels of serum thyroid-stimulating hormone (TSH). The most common form of RTH is familial with autosomal dominant inheritance (Olateju \& Vanderpump 2006, Dumitrescu \& Refetoff 2013). Clinical features include goiter, short stature, decreased weight, tachycardia, hearing loss, attention deficit hyperactivity disorder, decreased IQ, and dyslexia (Olateju \& Vanderpump 2006, Dumitrescu \& Refetoff 2013). Soon after the identification of the THRB gene, it was established that RTH is caused by mutations of the THRB gene. To date, about 100 different mutations in the THRB gene have been reported in more than 300 families (Olateju \& Vanderpump 2006).

After the discovery that RTH is caused by mutations of the THRB gene, there was intensive investigation to elucidate how TR $\beta$ mutations could function as dominant negative mutants to result in the symptoms of affected patients. Earlier work on the characterization of TR $\beta$ mutants and elucidation of their molecular actions in RTH mainly used in vitro biochemical methods. It soon became clear that these approaches have limitations when one tries to extrapolate to the physiological context. I realized that using the powerful genetic approach to create a mouse model of RTH would be more relevant for ascertaining the in vivo actions of TR $\beta$ mutants, and addressing clinically relevant questions. Moreover, such a mouse model would also yield insights into the functions of WT TRs. We, therefore, targeted a mutation known as TRßPV, identified in an RTH patient, to the Thrb gene locus (the $T h r b^{P V}$ mouse) via homologous recombination (Kaneshige et al. 2000). TRßPV has an unusual mutation in exon 10, a C-insertion at codon 448 , which produces a frameshift of the carboxyl-terminal 14 amino acids of TR $\beta 1$. TR $\beta P V$ has completely lost $\mathrm{T}_{3}$ binding and transcriptional activity and exhibits potent dominant negativity. Consistent with phenotypes of RTH patients, $T h r b^{P V}$ mice also exhibit growth retardation (Kaneshige et al. 2000), abnormal regulation of serum cholesterol
(Kamiya et al. 2003), hearing defects (Griffith et al. 2002), and thyrotoxic skeletal phenotype (O'Shea et al. 2006). These phenotypes indicate that the $T h r b^{P V}$ mouse is a valid model for studying the molecular basis of human RTH.

Using this mouse model, we were able to clarify several intriguing features of RTH. It was puzzling that the clinical manifestations vary between families with different mutations, between families with the same mutation, and also between members of the same family with identical mutations. Using mice from the cross of the $T h r b^{P V}$ mice with mice deficient in the steroid hormone receptor coactivator 1 (SRC1; SRC-1KO mice), we showed that lack of SRC1 modulates the degree of resistance to thyroid hormone in a target-tissue-dependent manner and alters abnormal expression patterns of several $T_{3}$ target genes in tissues (Kamiya et al. 2003). Thus, complex regulation of actions of TR $\beta$ mutants leads to varied manifestations of RTH phenotypes. Moreover, using the mice from the cross of the $T h r b^{P V}$ mice with mice deficient in the Thra gene (Thra ${ }^{-/-}$mice), we showed that $T h r b^{P V}$ mice deficient in TR $\alpha 1$ had worsened dysregulation of the thyroid-pituitary axis compared with $T h r b^{P V}$ mice and more severe impairment of postnatal growth (Suzuki \& Cheng 2003). One can deduce, therefore, that TR $\alpha 1$ plays an important and previously unrecognized compensatory role in maintaining the physiological functions of $T_{3}$ in heterozygous patients with RTH.

We also used the $T h r b^{P V}$ mice to address the important question as to how TR $\beta$ mutants could act as dominant negative mutations to cause the clinical symptoms. Cellbased studies by many have shown that constitutive recruitment of NCOR1/NCOR2 was critical to the dominant negative phenotype of TR $\beta$ mutants. However, the direct in vivo role of NCOR1 in modulating the dominant negative phenotype of TR $\beta$ mutants was demonstrated using mice produced from the cross of $T h r b^{P V}$ mice with mice expressing a NCOR1 mutant (NCOR1 $\triangle \mathrm{ID})$ that cannot interact with TR $\beta P V$ (Ncor ${ }^{\triangle I D}$ mice). It is remarkable that, in the presence of NCOR1 $\triangle \mathrm{ID}$, the abnormally elevated TSH and thyroid hormone levels found in $T h r b^{P V}$ mice were modestly but significantly corrected. Furthermore, thyroid hyperplasia, weight loss, and other hallmarks of RTH were also partially reverted in mice expressing NCOR1 $\mathrm{ID}$. Thus, for the first time, to our knowledge, unequivocal in vivo evidence was present to indicate that the aberrant recruitment of NCOR1 by RTH TR $\beta$ mutants leads to clinical RTH in humans (Fozzatti et al. 2011). The findings from these in vivo studies also raised the hope that therapies aimed at the TR-NCOR1 interaction or its downstream actions could be tested as potential targets

Published by Bioscientifica Ltd. 
for treating RTH. I was, indeed, very gratified that the $T h r b^{P V}$ mouse that we created had advanced our understanding of the molecular basis of RTH.

The creation of the $T h r b^{P V}$ mouse and its use in studying RTH led us to ask the question whether mutations of the THRA gene could also be involved. In view of the fact that mutations of the THRB gene were shown to cause RTH, and given the extensive sequence homology in the functional domains of TR $\alpha$ and TR $\beta$ and their similar in vitro functional characteristics, it was intriguing that no mutation of the THRA gene had ever been found in RTH patients. I was pondering whether mutations of the THRA gene could be embryonic lethal, inconsequential, or not associated with abnormalities of RTH. To sort out these possibilities and to gain new insights into the molecular actions of TR $\alpha$ mutants in vivo, we prepared another mutant mouse by targeting the identical PV mutation to the Thra gene locus to yield a mutant protein (TR $\alpha 1 \mathrm{PV})$ with the mutation site corresponding to that in TR $\beta P V$. Thra $1^{P V /+}$ mice are viable, indicating that the mutation of the THRA gene is not embryonic lethal. Unexpectedly, in drastic contrast to the $T h r b^{P V /+}$ mice, which do not exhibit a growth abnormality, Thra1 ${ }^{\mathrm{PV} /+}$ mice are dwarfs. These dwarfs exhibit increased mortality and reduced fertility. In contrast to $T h r b^{P V /+}$ mice, which have a hyperactive thyroid, Thra1 ${ }^{P V /+}$ mice exhibit mild thyroid failure (Kaneshige et al. 2001). The distinct phenotypes exhibited by $\mathrm{Thra}^{P V /+}$ and $T h r b^{P V /+}$ mice indicated for the first time, to our knowledge, that the in vivo functions of TR mutants are clearly isoform-dependent and explained why mutations of the THRA gene had never been found in RTH patients. While it was clear that the phenotypic expression of Thra1 ${ }^{P V /+}$ mice was drastically distinct from that of $T h r b^{P V /+}$ mice, inferences from this observation were limited by the fact that there were no known patients with mutations of the THRA gene and the fact that a PV mutation from a RTH patient was artificially targeted to the THRA gene. Thus, the relevance of the Thra1 ${ }^{P V /+}$ mouse as a model of human disease was uncertain for many years.

Excitingly, the discovery of patients with mutations of the THRA gene 12 years later after the making of the Thral $^{P V /+}$ mouse has lifted the cloud of doubt hanging over the validity of Thra1 ${ }^{P V /+}$ mouse as a disease model (Bochukova etal. 2012, van Mullem etal. 2012). Much to our amazement, TR $\alpha 1 P V$ shares the same mutated C-terminal sequence (-TLPRGL) with truncated termination at amino acid L406 as the proteins of two patients with frameshift mutations of the THRA gene (van Mullem et al. 2012). Patients with mutations of the THRA gene display classic features of hypothyroidism with growth and developmental retardation, skeletal dysplasia, and severe constipation, but with only borderline-abnormal thyroid hormone levels (Bochukova et al. 2012, van Mullem et al. 2012, Moran et al. 2013, 2014). These symptoms are similar to the phenotypic manifestations of the Thra ${ }^{P V /+}$ mouse.

The Thra $1^{P V /+}$ mouse is, thus, an ideal disease model to predict the skeletal outcome of human THRA mutations and determine whether prolonged treatment with a supraphysiological dose of $\mathrm{T}_{4}$ ameliorates the skeletal abnormalities. It was demonstrated that $\mathrm{T}_{4}$ treatment suppressed TSH secretion, but it had no effect on skeletal maturation, linear growth, or bone mineralization. Despite this, prolonged $\mathrm{T}_{4}$ treatment abnormally increased bone stiffness and strength, indicating the potential for detrimental consequences in the long term (Bassett et al. 2014). These results further established that TR $\alpha 1$ has an essential role in the developing and adult skeleton and it was predicted that patients with different THRA mutations will display variable responses to $\mathrm{T}_{4}$ treatment, which depend on the severity of the causative mutation. Moreover, in Thra $1^{P V /+}$ mice expressing the Ncor1 ${ }^{\Delta I D}$ gene, NCOR1 $\Delta$ ID ameliorated abnormalities in the thyroid-pituitary axis of Thra $1^{P V /+}$ mice. The severely retarded growth, infertility, and delayed bone development were partially reverted in $T h r a 1^{P V /+}$ mice expressing NCOR1AID (Fozzatti et al. 2013). Thus, Thra1 ${ }^{P V /+}$ mice allowed us to show that aberrant recruitment of NCOR1 by TR $\alpha 1$ mutants could lead to clinical hypothyroidism in humans. These findings could pave the way for considering therapies aimed at the TR $\alpha 1-N C O R 1$ interaction or its downstream actions.

Taken together, the results of our studies thus far have demonstrated that $T h r a 1^{P V /+}$ and $T h r b^{P V /+}$ mice are ideal disease models for elucidating the molecular basis of human diseases and identifying potential molecular targets for novel strategies. Moreover, these two mutant mice are ideal for elucidating the molecular basis of isoform-dependent actions in vivo. These two mutant mice express an identical mutation located at the same corresponding C-terminal site of the two TR isoforms; therefore, the effects due to type and sites of mutation could be eliminated. Studies of the isoform-dependent actions in vivo will lead to understanding of the biology and functions of receptor isoforms not only for TRs, but also for other steroid hormone nuclear receptors.

The unexpected finding that as the homozygous $T h r b^{P V / P V}$ mice aged they spontaneously developed follicular thyroid carcinoma similar to the human cancer has opened a new field of investigation into the role of TR $\beta$ mutants in carcinogenesis (Suzuki et al. 2002). Only three

Published by Bioscientifica Ltd. 
patients homozygous for mutant TR $\beta$ have been reported so far. These patients display a complex phenotype of extreme RTH with markedly higher levels of thyroid hormone and TSH than those described for all heterozygous patients reported. However, whether these patients develop disease other than RTH is unknown. The fact that $T h r b^{P V / P V}$ mice spontaneously develop follicular thyroid carcinoma indicates that TR $\beta$ mutants could cause disease beyond RTH. The altered signaling pathways during thyroid carcinogenesis of $T h r b^{P V / P V}$ mice have been extensively characterized. Over-activation of tumor promoters such as cyclin D1 (Ying et al. 2003), $\beta$-catenin (Guigon et al. 2008), phosphoinositide-3-kinase (PI3K) (Furuya et al. 2006), and the pituitary tumor-transforming gene (Ying et al. 2006, Kim et al. 2007) drives thyroid cancer progression in Thrb ${ }^{P V / P V}$ mice. Thyroid cancer progression is accelerated by repression of tumor suppressors such as the peroxisome proliferator-activated receptor $\gamma(\operatorname{PPAR} \gamma)$. These altered signaling pathways during thyroid carcinogenesis of $T h r b^{P V / P V}$ mice are consistent with the changes reported for carcinogenesis in the human thyroid. The potential molecular targets identified in these altered signaling pathways were tested in $T h r b^{P V / P V}$ mice. $T h r b^{P V / P V}$ mice treated with an agonist to activate the tumor-suppressing activity of PPAR $\gamma$ exhibit marked delay in tumor progression, increased survival, and no apparent metastasis. Moreover, treatment of $T h r b^{P V / P V}$ mice with LY294002 (LY), a potent and specific PI3K inhibitor, delays thyroid tumor progression and blocks metastatic spread to the lung (Furuya et al. 2007). The results of these studies firmly established that the $T h r b^{P V / P V}$ mouse is an ideal preclinical mouse model not only for understanding the molecular genetics of thyroid cancer, but also for elucidating the molecular basis of oncogenic actions of TR $\beta 1$ mutants in vivo.

Indeed, we have used the $T h r b^{P V / P V}$ mouse model to address a longstanding issue debated for years on the role of TSH in thyroid carcinogenesis. The fact that the $T h r b^{P V / P V}$ mice exhibit highly elevated TSH with spontaneous development of follicular thyroid cancer has provided an opportunity to clarify this issue. Using mice from the cross of $T h r b^{P V / P V}$ mice with TSH receptor (TSHR) knockout mice ( $T s h r^{-/-}$mice) to eliminate the effect of TSH-TSHR signaling during carcinogenesis, we showed that growth stimulated by TSH is a prerequisite, but not sufficient for metastatic cancer to occur. Additional genetic alterations (such as TR $\beta$ PV), destined to alter focal adhesion and migration capacities, are required to empower hyperplastic follicular cells to invade and to metastasize (Lu et al. 2010).
We have also introduced other oncogenes into the $T h r b^{P V / P V}$ mouse in order to understand how other oncogenes could affect follicular thyroid cancer. For example, we generated $T h r b^{P V / P V}$ mice with haplodeficiency of the Pten gene (Thrb ${ }^{P V / P V}$ Pten $^{+/-}$mice) to clarify the role of PTEN in thyroid cancer (Guigon et al. 2009). Insufficiency of PTEN accelerates tumor progression by further activating aberrant PI3K-AKT signaling, thereby establishing that PTEN is a critical regulator in follicular thyroid cancer progression and invasiveness (Guigon et al. 2009). This $\mathrm{Thrb}^{\mathrm{PV} / \mathrm{PV}} \mathrm{Pten}^{+/-}$mouse has been used as a preclinical mouse model to test Src as a potential target. Treatment of $\mathrm{Thrb}^{P V / P V} \mathrm{Pten}^{+/-}$mice with an Src inhibitor, SKI-606 (bosutinib), effectively inhibits aberrant activation of Src and its downstream targets to markedly inhibit the growth of thyroid tumor, thereby prolonging the survival of treated mice (Kim et al. 2012).

We have also genetically targeted the Kras ${ }^{G 12 D}$ mutation to thyroid epithelial cells of $T h r b^{P V / P V}$ mice to determine how the Kras ${ }^{G 12 D}$ mutation could induce undifferentiated thyroid cancer in $T h r b^{P V / P V}{ }^{K r a s}{ }^{G 12 D}$ mice. Thrb ${ }^{P V / P V}{ }^{K r a s}{ }^{G 12 D}$ mice exhibited poorer survival because of more aggressive thyroid tumors with capsular invasion, vascular invasion, and distant metastases to the lung occurring at an earlier age and at a higher frequency than did $T h r b^{P V / P V}$ mice. However, mice expressing KRASG12D ( $\mathrm{Kras}^{G 12 D}$ mice) alone did not develop thyroid cancer. Remarkably, Thrb ${ }^{P V / P V}$ Kras ${ }^{G 12 D}$ mice developed frequent anaplastic foci with complete loss of normal thyroid follicular morphology. Within the anaplastic foci, expression of the thyroid-specific transcription factor paired box gene 8 (PAX8) was virtually lost, and the loss of PAX8 expression was inversely correlated with elevated MYC expression (Zhu et al. 2014a). Further molecular analyses uncovered integrin-activated ERBB2 signaling as one of the mechanisms involved in synergy between TR $\beta P V$ and KRASG12D signaling to promote aggressive tumor growth in undifferentiated thyroid cancer (Zhu et al. $2014 b$ ). Thus, the $T h r b^{P V / P V} \operatorname{Kras}^{G 12 D}$ mouse could be used as a model of undifferentiated thyroid cancer for further elucidating genetic changes during the de-differentiation process and to identify potential molecular targets for novel treatment modalities for anaplastic thyroid cancer.

During our studies of the $T h r b^{P V / P V}$ mouse as a preclinical model for follicular thyroid cancer we have identified in vivo aberrant signaling pathways contributing to thyroid carcinogenesis that were previously unidentifiable without the model. Importantly, novel molecular mechanisms of TR $\beta$ mutations in carcinogenesis have been revealed. TR $\beta P V$ acts as an oncogene via multiple molecular

Published by Bioscientifica Ltd 
mechanisms. It can function by interfering with the transcription activity of WT TRs by abnormal repression of the expression of tumor suppressors (e.g., PPAR $\gamma$ ). TR $\beta P V$ can also function via extra-nuclear sites, by initiating the actions via direct protein-protein interaction with key cellular regulators such as PI3K, integrins, FAK, $\beta$-actin, and erzin. Through phosphorylation cascades, the signals initiated by the interaction of TR $\beta P V$ with these regulators are transduced to activate downstream pathways, such as PI3K-AKT-mTOR signaling and MAPK signaling, to promote cancer cell proliferation, apoptosis, migration, and invasion. The discovery of these complex actions of TR $\beta P V$ revealed that thyroid carcinogenesis resulted from alterations in multiple signaling pathways. The identification of these altered cellular pathways provides new opportunities for evaluating potential molecular targets for diagnosis and treatments. Several potential molecular targets have been tested and shown to be effective in delaying thyroid cancer progression and preventing metastasis.

Still, many challenges lie ahead. At present, no thyroid cancer has been detected in heterozygous $T h r b^{P V /+}$ mice. Results of our studies indicate that TR $\beta P V$ is oncogenic via collaboration with other key regulators in homozygous $T h r b^{P V / P V}$ mice to bring about thyroid cancer. It is imperative to identify the factors with which TR $\beta P V$ collaborates to invoke its oncogenic activity in heterozygous $T h r b^{P V /+}$ mice. Addressing this key issue will shed new light on why RTH patients, who are mostly heterozygous for a mutation of a single allele of the THRB gene, have no increased propensity for developing thyroid cancer. Besides thyroid cancer, TR $\beta P V$ has been shown to play key roles in the development of pituitary tumors (Furumoto et al. 2005) and breast cancer (Guigon et al. 2011), indicating that the oncogenic actions of TR $\beta P V$ are not restricted to thyroid alone. Further identification of other target organs that are affected by the expression of TR $\beta P V$ could shed new light on the understanding of somatic mutations in human cancers such as hepatocellular carcinomas (Lin et al. 1999) and renal carcinomas reported previously by others (Kamiya et al. 2002). Addressing these challenges and others that may emerge subsequently will certainly lead to recognition and appreciation of the important roles of TRs in cancer biology.

Looking back, it seems that my scientific journey was shaped more by circumstances and opportunities than by choices of available and workable options to determine my path. I always wonder if I had had a top-ranked academic pedigree, would I have traveled farther in my career and would my journey have been decorated with more prizes, awards, and recognition? That is a 'what if' question that I will never know the answer to, and so I reflect on 'what is.' I am gratified that my humble contributions could have advanced our understanding of thyroid hormone actions. I also know that, in spite of many limitations, I have done what I could with the opportunities presented to me. Shortly after I became a tenured independent investigator at NCI, my father became gravely ill. I flew back to Taiwan to say a final goodbye. There was very little time to tell him about my professional position, and the details of my work. So, I just told him in Chinese that I had become a scholar. He nodded with a proud smile on his pale face. While I am not sure whether a researcher is the same as a scholar, for my father, the word scholar was what he had been waiting to hear from me. I fully appreciate that my father's wish was the initial impetus for me to begin my life's journey on the path of scientific pursuit. However, it is an intrinsic drive to know the truth framed as 'why' and 'how' questions, a persistence in seeking the answers, and the occasional sparks of joy from interesting and important discoveries, small or huge, that have sustained the long journey.

At each stage of my journey, from the PhD work on the synthesis of non-classical androgen analogs to very brief work on estrogen receptors, to the study of thyroid hormone-binding proteins, and to the mouse modeling of human diseases, there were many, to whom I am indebted, who encouraged and supported me on the journey, offering a hand if I stumbled. I am forever grateful to: Dr Cahnmann for taking me under his wing when nobody would; to Dr Pastan for the exceptional opportunity to launch my own research; to my lifetime collaborator, Dr Willingham, who educates me, a chemist, on the amazing biology of the cell, and the normal and abnormal histology of tissues; to my many collaborators for their generous gifts of reagents and for sharing of ideas and valuable discussions; and to the many fellows who have trusted me in mentoring their career development. Most importantly, I could not have undertaken my journey without my husband's unconditional support and my children's understanding when I occasionally missed their story time, music recitals, and soccer championship games. I am truly grateful to all my family members who have been with me on this journey.

It is my sincere hope that those of us who are in a position to do so will look for opportunities and take the time to provide guidance generously to young investigators who have their hearts and minds set on research. They bring to science curiosity and inquisitive minds, willingness to endure disappointments and frustration,

Published by Bioscientifica Ltd 
and optimistic expectations of the joy of discovery. But, too often, they are uncertain where to go and what to do. I hope I can do for a new generation of scientists what Dr Cahnmann did for me when I knocked on his laboratory door on the 8th floor of Building 10 at NIH many years ago and changed my fate to my destiny.

\section{Declaration of interest}

The author declares that there is no conflict of interest that could be perceived as prejudicing the impartiality of this profile.

\section{Funding}

This profile did not receive any specific grant from any funding agency in the public, commercial or not-for-profit sector.

\section{Acknowledgements}

I regret any reference omissions due to length limitations. I wish to thank all my colleagues and collaborators who have contributed to the work described in this article. The research described in this article by the authors and their colleagues at the National Cancer Institute was supported by the Intramural Research Program of the Center for Cancer Research, National Cancer Institute, National Institutes of Health.

\section{References}

Ashizawa K \& Cheng SY 1992 Regulation of thyroid hormone receptormediated transcription by a cytosol protein. PNAS 89 9277-9281. (doi:10.1073/pnas.89.19.9277)

Ashizawa K, McPhie P, Lin KH \& Cheng SY 1991 An in vitro novel mechanism of regulating the activity of pyruvate kinase M2 by thyroid hormone and fructose 1, 6-bisphosphate. Biochemistry 30 7105-7111. (doi:10.1021/bi00243a010)

Ashizawa K, Fukuda T \& Cheng SY 1992 Transcriptional stimulation by thyroid hormone of a cytosolic thyroid hormone binding protein which is homologous to a subunit of pyruvate kinase M1. Biochemistry 31 2774-2778. (doi:10.1021/bi00125a018)

Bassett JH, Boyde A, Zikmund T, Evans H, Croucher PI, Zhu X, Park JW, Cheng SY \& Williams GR 2014 Thyroid hormone receptor $\alpha$ mutation causes a severe and thyroxine-resistant skeletal dysplasia in female mice. Endocrinology 155 3699-3712. (doi:10.1210/en.2013-2156)

Bochukova E, Schoenmakers N, Agostini M, Schoenmakers E, Rajanayagam O, Keogh JM, Henning E, Reinemund J, Gevers E, Sarri M et al. 2012 A mutation in the thyroid hormone receptor alpha gene. New England Journal of Medicine 366 243-249. (doi:10.1056/NEJMoa1110296)

Cheng SY, Maxfield FR, Robbins J, Willingham MC \& Pastan IH 1980 Receptor-mediated uptake of 3,3',5-triiodo-L-thyronine by cultured fibroblasts. PNAS 77 3425-3429. (doi:10.1073/pnas.77.6.3425)

Cheng SY, Hasumura S, Willingham MC \& Pastan I 1986 Purification and characterization of a membrane-associated 3,3',5-triiodo-L-thyronine binding protein from a human carcinoma cell line. PNAS 83 947-951. (doi:10.1073/pnas.83.4.947)

Cheng SY, Gong QH, Parkison C, Robinson EA, Appella E, Merlino GT \& Pastan I 1987 The nucleotide sequence of a human cellular thyroid hormone binding protein present in endoplasmic reticulum. Journal of Biological Chemistry 262 11221-11227.
Cheng SY, Leonard JL \& Davis PJ 2010 Molecular aspects of thyroid hormone actions. Endocrine Reviews 31 139-170. (doi:10.1210/ er.2009-0007)

Davis PJ, Davis FB, Mousa SA, Luidens MK \& Lin HY 2011 Membrane receptor for thyroid hormone: physiologic and pharmacologic implications. Annual Review of Pharmacology and Toxicology 51 99-115. (doi:10.1146/annurev-pharmtox-010510-100512)

Dumitrescu AM \& Refetoff S 2013 The syndromes of reduced sensitivity to thyroid hormone. Biochimica et Biophysica Acta 1830 3987-4003. (doi:10.1016/j.bbagen.2012.08.005)

Fozzatti L, Lu C, Kim DW, Park JW, Astapova I, Gavrilova O, Willingham MC, Hollenberg AN \& Cheng SY 2011 Resistance to thyroid hormone is modulated in vivo by the nuclear receptor corepressor (NCOR1). PNAS 108 17462-17467. (doi:10.1073/pnas.1107474108)

Fozzatti L, Kim DW, Park JW, Willingham MC, Hollenberg AN \& Cheng SY 2013 Nuclear receptor corepressor (NCOR1) regulates in vivo actions of a mutated thyroid hormone receptor $\alpha$. PNAS $1107850-7855$. (doi:10.1073/pnas.1222334110)

Furumoto H, Ying H, Chandramouli GV, Zhao L, Walker RL, Meltzer PS, Willingham MC \& Cheng SY 2005 An unliganded thyroid hormone $\beta$ receptor activates the cyclin D1/cyclin-dependent kinase/retinoblastoma/E2F pathway and induces pituitary tumorigenesis. Molecular and Cellular Biology 25 124-135. (doi:10.1128/MCB.25.1.124-135.2005)

Furuya F, Hanover JA \& Cheng SY 2006 Activation of phosphatidylinositol 3-kinase signaling by a mutant thyroid hormone $\beta$ receptor. PNAS 103 1780-1785. (doi:10.1073/pnas.0510849103)

Furuya F, Lu C, Willingham MC \& Cheng SY 2007 Inhibition of phosphatidylinositol 3-kinase delays tumor progression and blocks metastatic spread in a mouse model of thyroid cancer. Carcinogenesis $\mathbf{2 8}$ 2451-2458. (doi:10.1093/carcin/bgm174)

Griffith AJ, Szymko YM, Kaneshige M, Quinonez RE, Kaneshige K, Heintz KA, Mastroianni MA, Kelley MW \& Cheng SY 2002 Knock-in mouse model for resistance to thyroid hormone (RTH): an RTH mutation in the thyroid hormone receptor beta gene disrupts cochlear morphogenesis. Journal of the Association for Research in Otolaryngology 3 279-288. (doi:10.1007/ s101620010092)

Guigon CJ, Zhao L, Lu C, Willingham MC \& Cheng SY 2008 Regulation of $\beta$-catenin by a novel nongenomic action of thyroid hormone $\beta$ receptor. Molecular and Cellular Biology 28 4598-4608. (doi:10.1128/ MCB.02192-07)

Guigon CJ, Zhao L, Willingham MC \& Cheng SY 2009 PTEN deficiency accelerates tumour progression in a mouse model of thyroid cancer. Oncogene 28 509-517. (doi:10.1038/onc.2008.407)

Guigon CJ, Kim DW, Willingham MC \& Cheng SY 2011 Mutation of thyroid hormone receptor- $\beta$ in mice predisposes to the development of mammary tumors. Oncogene 30 3381-3390. (doi:10.1038/onc.2011.50)

Kamiya Y, Puzianowska-Kuznicka M, McPhie P, Nauman J, Cheng SY \& Nauman A 2002 Expression of mutant thyroid hormone nuclear receptors is associated with human renal clear cell carcinoma. Carcinogenesis 23 25-33. (doi:10.1093/carcin/23.1.25)

Kamiya Y, Zhang XY, Ying H, Kato Y, Willingham MC, Xu J, O'Malley BW \& Cheng SY 2003 Modulation by steroid receptor coactivator-1 of target-tissue responsiveness in resistance to thyroid hormone. Endocrinology 144 4144-4153. (doi:10.1210/en.2003-0239)

Kaneshige M, Kaneshige K, Zhu X, Dace A, Garrett L, Carter TA, Kazlauskaite R, Pankratz DG, Wynshaw-Boris A, Refetoff S et al. 2000 Mice with a targeted mutation in the thyroid hormone $\beta$ receptor gene exhibit impaired growth and resistance to thyroid hormone. PNAS 97 13209-13214. (doi:10.1073/pnas.230285997)

Kaneshige M, Suzuki H, Kaneshige K, Cheng J, Wimbrow H, Barlow C, Willingham MC \& Cheng S 2001 A targeted dominant negative mutation of the thyroid hormone $\alpha 1$ receptor causes increased mortality, infertility, and dwarfism in mice. PNAS 98 15095-15100. (doi:10.1073/pnas.261565798)

Published by Bioscientifica Ltd. 
Kato H, Fukuda T, Parkison C, McPhie P \& Cheng SY 1989 Cytosolic thyroid hormone-binding protein is a monomer of pyruvate kinase. PNAS $\mathbf{8 6}$ 7861-7865. (doi:10.1073/pnas.86.20.7861)

Kim CS, Ying H, Willingham MC \& Cheng SY 2007 The pituitary tumortransforming gene promotes angiogenesis in a mouse model of follicular thyroid cancer. Carcinogenesis 28 932-939. (doi:10.1093/ carcin/bgl231)

Kim WG, Guigon CJ, Fozzatti L, Park JW, Lu C, Willingham MC \& Cheng SY 2012 SKI-606, an Src inhibitor, reduces tumor growth, invasion, and distant metastasis in a mouse model of thyroid cancer. Clinical Cancer Research 18 1281-1290. (doi:10.1158/1078-0432.CCR-11-2892)

Kitagawa S, Obata T, Hasumura S, Pastan I \& Cheng SY 1987 A cellular $3,3^{\prime}, 5$-triiodo-L-thyronine binding protein from a human carcinoma cell line. Purification and characterization. Journal of Biological Chemistry 262 3903-3908.

Lin KH, Shieh HY, Chen SL \& Hsu HC 1999 Expression of mutant thyroid hormone nuclear receptors in human hepatocellular carcinoma cells. Molecular Carcinogenesis 26 53-61. (doi:10.1002/(SICI)1098-2744 (199909)26:1 < 53::AID-MC7 > 3.0.CO;2-Z)

Lin HY, Cody V, Davis FB, Hercbergs AA, Luidens MK, Mousa SA \& Davis PJ 2011 Identification and functions of the plasma membrane receptor for thyroid hormone analogues. Discovery Medicine 11 337-347.

Lu C, Zhao L, Ying H, Willingham MC \& Cheng SY 2010 Growth activation alone is not sufficient to cause metastatic thyroid cancer in a mouse model of follicular thyroid carcinoma. Endocrinology 151 1929-1939. (doi:10.1210/en.2009-1017)

Maxfield FR, Schlessinger J, Shechter Y, Pastan I \& Willingham MC 1978 Collection of insulin, EGF and $\alpha_{2}$-macroglobulin in the same patches on the surface of cultured fibroblasts and common internalization. Cell 14 805-810. (doi:10.1016/0092-8674(78)90336-7)

Mayerl S, Muller J, Bauer R, Richert S, Kassmann CM, Darras VM, Buder K, Boelen A, Visser TJ \& Heuer H 2014 Transporters MCT8 and OATP1C1 maintain murine brain thyroid hormone homeostasis. Journal of Clinical Investigation 124 1987-1999. (doi:10.1172/JCI70324)

Moran C, Schoenmakers N, Agostini M, Schoenmakers E, Offiah A, Kydd A, Kahaly G, Mohr-Kahaly S, Rajanayagam O, Lyons G et al. 2013 An adult female with resistance to thyroid hormone mediated by defective thyroid hormone receptor $\alpha$. Journal of Clinical Endocrinology and Metabolism 98 4254-4261. (doi:10.1210/jc.2013-2215)

Moran C, Agostini M, Visser WE, Schoenmakers E, Schoenmakers N, Offiah AC, Poole K, Rajanayagam O, Lyons G, Halsall D et al. 2014 Resistance to thyroid hormone caused by a mutation in thyroid hormone receptor (TR) $\alpha 1$ and TR $\alpha 2$ : clinical, biochemical, and genetic analyses of three related patients. Lancet. Diabetes \& Endocrinology 2 619-626. (doi:10.1016/S2213-8587(14)70111-1) van Mullem A, van Heerebeek R, Chrysis D, Visser E, Medici M, Andrikoula M, Tsatsoulis A, Peeters R \& Visser TJ 2012 Clinical phenotype and mutant
TR $\alpha 1$. New England Journal of Medicine 366 1451-1453. (doi:10.1056/ NEJMc1113940)

Olateju TO \& Vanderpump MP 2006 Thyroid hormone resistance. Annals of Clinical Biochemistry 43 431-440. (doi:10.1258/000456306778904678)

O'Shea PJ, Bassett JH, Cheng SY \& Williams GR 2006 Characterization of skeletal phenotypes of TR $\alpha 1^{\mathrm{PV}}$ and TR $\beta^{\mathrm{PV}}$ mutant mice: implications for tissue thyroid status and $\mathrm{T}_{3}$ target gene expression. Nuclear Receptor Signaling 4 e011. (doi:10.1621/nrs.04011)

Refetoff S, DeWind LT \& DeGroot LJ 1967 Familial syndrome combining deaf-mutism, stuppled epiphyses, goiter and abnormally high PBI: possible target organ refractoriness to thyroid hormone. Journal of Clinical Endocrinology and Metabolism 27 279-294. (doi:10.1210/ jcem-27-2-279)

Sap J, Munoz A, Damm K, Goldberg Y, Ghysdael J, Leutz A, Beug H \& Vennstrom B 1986 The c-erb-A protein is a high-affinity receptor for thyroid hormone. Nature 324 635-640. (doi:10.1038/324635a0)

Schweizer U, Johannes J, Bayer D \& Braun D 2014 Structure and function of thyroid hormone plasma membrane transporters. European Thyroid Journal 3 143-153. (doi:10.1159/000367858)

Suzuki H \& Cheng SY 2003 Compensatory role of thyroid hormone receptor (TR) $\alpha 1$ in resistance to thyroid hormone: study in mice with a targeted mutation in the TR $\beta$ gene and deficient in TR $\alpha 1$. Molecular Endocrinology 17 1647-1655. (doi:10.1210/me.2003-0114)

Suzuki H, Willingham MC \& Cheng SY 2002 Mice with a mutation in the thyroid hormone receptor $\beta$ gene spontaneously develop thyroid carcinoma: a mouse model of thyroid carcinogenesis. Thyroid $\mathbf{1 2}$ 963-969. (doi:10.1089/105072502320908295)

Weinberger C, Thompson CC, Ong ES, Lebo R, Gruol DJ \& Evans RM 1986 The $c$-erb- $A$ gene encodes a thyroid hormone receptor. Nature $\mathbf{3 2 4}$ 641-646. (doi:10.1038/324641a0)

Willingham MC \& Pastan I 1978 The visualization of fluorescent proteins in living cells by video intensification microscopy (VIM). Cell $\mathbf{1 3}$ 501-507. (doi:10.1016/0092-8674(78)90323-9)

Ying H, Suzuki H, Furumoto H, Walker R, Meltzer P, Willingham MC \& Cheng SY 2003 Alterations in genomic profiles during tumor progression in a mouse model of follicular thyroid carcinoma. Carcinogenesis 24 1467-1479. (doi:10.1093/carcin/bgg111)

Ying H, Furuya F, Zhao L, Araki O, West BL, Hanover JA, Willingham MC \& Cheng SY 2006 Aberrant accumulation of PTTG1 induced by a mutated thyroid hormone $\beta$ receptor inhibits mitotic progression. Journal of Clinical Investigation 116 2972-2984. (doi:10.1172/JCI28598)

Zhu X, Zhao L, Park JW, Willingham MC \& Cheng SY 2014a Synergistic signaling of KRAS and thyroid hormone receptor $\beta$ mutants promotes undifferentiated thyroid cancer through MYC up-regulation. Neoplasia 16 757-769. (doi:10.1016/j.neo.2014.08.003)

Zhu X, Zhu YJ, Kim DW, Meltzer P \& Cheng SY 2014b Activation of integrin-ERBB2 signaling in undifferentiated thyroid cancer. American Journal of Cancer Research 4 776-788.

Received in final form 3 February 2015

Accepted 5 February 2015

Made available online as an Accepted Preprint

5 February 2015 http://erc.endocrinology-journals.org DOI: 10.1530/ERC-15-0056
(C) 2015 Society for Endocrinology Printed in Great Britain
Published by Bioscientifica Ltd 